\title{
Maize stemborers distribution, their natural enemies and farmers' perception on climate change and stemborers in southern Togo
}

\author{
Tounou Agbéko Kodjo1*, Agboka Komi' ${ }^{1}$, Agbodzavu Komi Mawufe ${ }^{2}$ and Wegbe Komlan² \\ 1 Ecole Supérieure d'Agronomie (ESA), Université de Lomé (UL), BP 1515, Lomé (Togo) \\ ${ }^{2}$ Centre de Recherche Agronomique-zone Forêt (CRA-F), Institut Togolais de Recherche Agronomique (ITRA), BP. \\ 90 Kpalimé (Togo) \\ *Corresponding author: Dr. TOUNOU Agbéko Kodjo, ESA/UL BP 1515 Lomé (Togo), Email: ktounou@gmail.com
}

Original submitted in on 10th January 2013. Published online at www.m.elewa.org on 25 th April 2013.

http://dx.doi.org/10.4314/jab.v64i1.88466

\begin{abstract}
Objective: The objectives of this study were to (i) assess the importance of the different stemborer species and their associated natural enemies on maize, and (ii) evaluate cereal producers' perception on the effect of the current climate variability, on the maize stem and ear borers and their mitigation strategies to alleviate the impact of climate change on their cropping system.

Methodology and results: Surveys were conducted in 2012 during the long cropping season lasting from March to July and the short one from September to October in southern Togo, to determine geographic distribution, relative importance of lepidopterous stemborers and their parasitism by natural enemies on maize. A questionnaire was introduced to evaluate cereal farmers' perception of climate change and its effects on maize stem and ear borers. Of the total borer species recovered, the most abundant was Sesamia calamistis Hampson (Lepidoptera: Noctuidae) (76.02\%), followed by Busseola fusca Füller (Lepidoptera: Noctuidae) (21.71\%) and then Eldana saccharina Walker (Lepidoptera: Pyralidae) $(2.27 \%)$. The borers' abundance was affected by the agroecological zones and cropping seasons. Eldana saccharina was found in Zio and Yoto in coastal zone whereas $B$. fusca was recorded only in Yoto. Sesamia calamistis was the only species found in all the surveyed agroecological zones (III, IV and V). Fields were infested by all borer species at $34.4 \%$ and $83.3 \%$ in the long and short cropping seasons respectively. The percentage of infested plants ranged from 0 to $72 \%$ in the first cropping season, and 33 to $95 \%$ in the second cropping season. The borer densities varied from 0 to 3 larvae per plant in the long cropping season and 1 to 8 larvae per plant in the short cropping season. The egg parasitoid Telenomus busseolae Gahan (Hymenoptera: Scelionidae) was identified as the most important with a high natural parasitism rate of $82 \%$ on S. calamistis. The main larval parasitoid recorded was Sturmiopsis parasitica Curan (Diptera: Tachnidae) with mean parasitism ranged of between 0 and $8 \%$. Beauveria bassiana (Bals.) Vuill. (Deuteromycotina: Hyphomycetes) infection rate vary from 0 to $5 \%$.of borers' larvae. Data on farmer's perception showed that all producers recognized stem and ear borers and their damages. However, they perceive climate change effects differently by high temperatures, rains irregularity, floods, strong winds and to a lesser extent the proliferation of new pests such as termites (Isoptera), Zonocerus variegatus $(L)$ (Orthoptera: Pyrgomorphidae) and Cicadulina spp. (Hemiptera: Cicadellidae). Adaptation strategies practiced
\end{abstract}


by farmers are the choice of early maturing crop varieties, the spacing of sowing period and the crop diversification.

Conclusion and application of funding: From these results, we conclude that S. calamistis, E. saccharina, and B. fusca and their associated natural enemies are present in all agroecological zones of southern Togo. These findings could serve as baseline data for further studies.

Key words: Climate change, ear borers, incidence, maize, parasitism, severity, stem borers.

\section{INTRODUCTION}

Cereals, especially maize, represent the most important food crops grown in most of sub-Sahara Africa (SSA), and has often been the focus of development policies. One of the challenges cereal farmers faced is the control of stem and ear borers' infestations which causes losses of up to about 10$70 \%$ in areas with severe borer problems (BosquePérez and Mareck 1991; Cardwell et al., 1997; Sétamou et al., 2000). Research conducted in most West African countries has shown that lepidopteran stem and ear borers are among the most economically important pests of maize. (see overview by Polaszek, 1998). The most commonly reported species are the pyralid Eldana saccharina Walker (Lepidoptera: Pyralidae), the noctuid Sesamia calamistis Hampson (Lepidoptera: Noctuidae), and the pyralid ear borer Mussidia nigrivenella Ragonot (Lepidoptera: Pyralidae) found in west of Dahomey gap, and in countries such as Ghana ,Nigeria and Côte d'Ivoire (Endrody-Younga, 1968; Bosque-Pérez and Mareck, 1990; Shanower et al., 1991; Gounou et al., 1994; Schulthess et al., 1997; Bosque-Pérez and Schulthess, 1998; Sétamou et al., 2000; Buadu et al., 2002). In the lowland tropics of West, East and southern Africa, the noctuid Busseola fusca Füller

\section{MATERIALS AND METHODS}

Survey sites: Surveys were conducted during the long and short cropping seasons of 2012 to evaluate the infestation levels of the different stemborer species and their associated natural enemies on maize crops in southern Togo. The southern Togo encompass three agroecological zones (AEZ) (Figure 1) and includes central plains characterized by dry forests and guinea savannah creating with grasses a mosaic (Zone III), southern part of the highlands covered by secondary forests (Zone IV) and scattered semi-deciduous forests with important lagoon depressions and associate
(Lepidoptera: Noctuidae) is generally of low importance but in Central African countries like Cameroon it is the predominant species across all eco-zones and altitudes (Moyal, 1988; Cardwell et al., 1997; Ndemah et al., 2001a). In Togo, detailed studies on cereal stem and ear borers are extremely limited. Since the surveys conducted by Silvie (1993) in restricted cereal and cotton-cropping areas, no large-scale quantitative surveys have been undertaken in the country. The abundance and distribution of stem-borer pests and their main natural enemies are expected to vary considerably with the current climate variability (Parmesan et al., 1999; Batalden et al., 2007; Trnka et al., 2007). The objectives of this study were to (i) assess the relative importance of the different stem borer species and their associated natural enemies on maize, and (ii) evaluate cereal producers' perception on the effect of the current climate variability, on the maize stem and ear borers and on their mitigation strategies to alleviate the impact of climate change on their cropping system. This study therefore provides the baseline data and undertake analyses that will allow for assessment of changes of pest distributions and associated yield losses in maize in Togo.

mangroves (Zone V) (Akpagana, 1992; Kokou,. 1998; Afidégnon 1999). Rainfall levels in the three AEZs are highly variable in timing, duration and intensity. Most of the localities surveyed have a bimodal rainfall distribution that allow for two cropping seasons, the first lasting between March and July (referred to as the long cropping season , LR) and the second from September to October (short cropping season, SR). However these rainfall patterns tend to become monomodal with the disappearance of the dry spell in August (DRP, 1985). 


\section{Legend \\ - Sampled sites \\ $\frown$ Main roads Agro- ecological
zone limit}

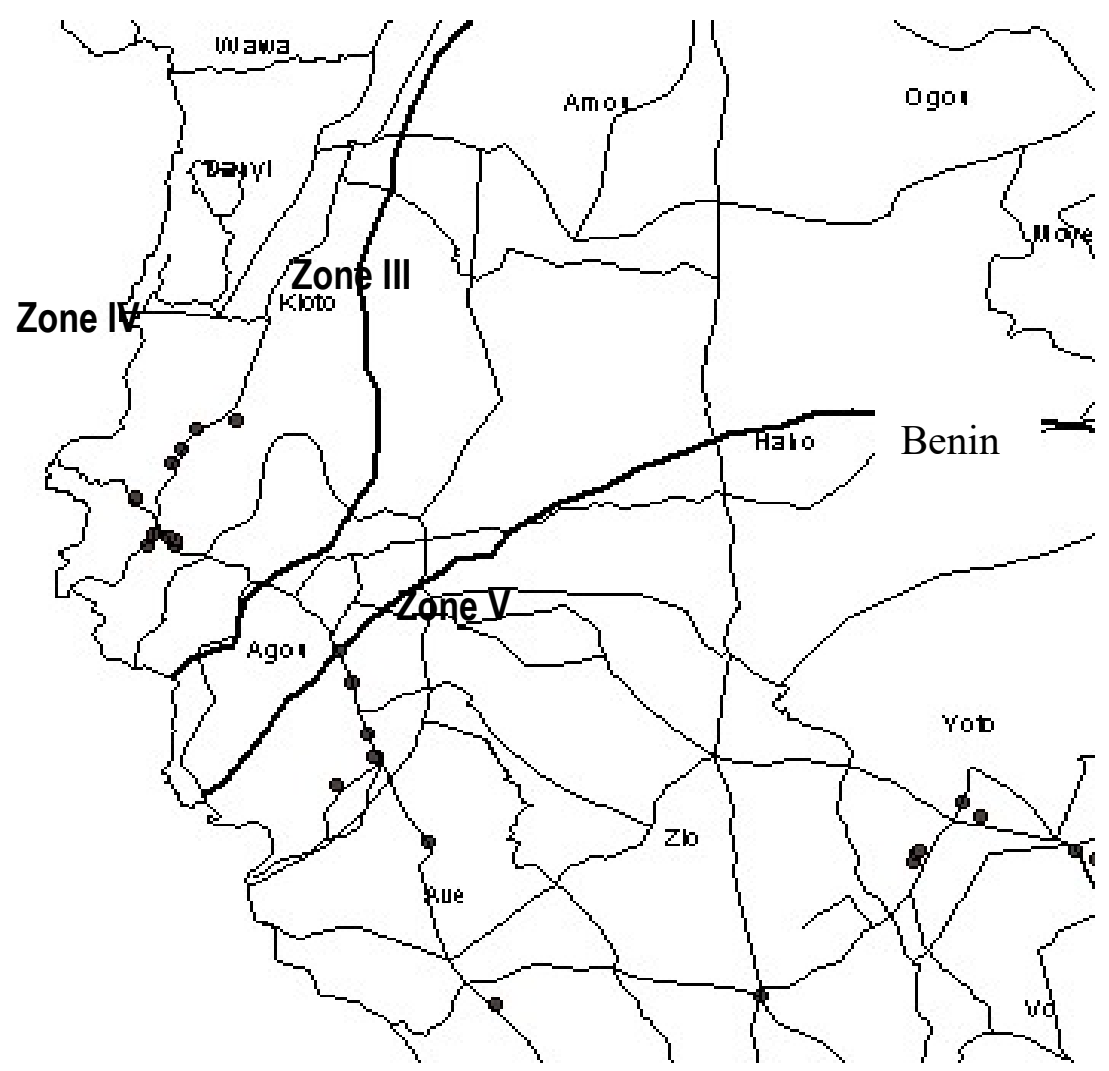

Atlantic Ocean

Figure 1: Agroecological zones (AEZs) and survey sites sampled in southern Togo

Sampling procedure: Destructive sampling was conducted two times, at vegetative and reproductive stage (tasseling and soft dough stages) during each cropping season. In each AEZ, evaluations were conducted in two to six districts where maize is the main cereal crop. Sampling sites were selected at 5-10 km intervals along major roads in the selected districts and each site was geo-referenced by global positioning system (GPS) (Garmin map 62stc). A total of 15-20 small scale farmers' maize fields each measuring approximately $0.5-1.5$ ha were sampled per AEZ. During both seasonal surveys, a complex of overlapping maize growth stages was observed probably because of different sowing dates due to climate variability. Each field sampled was divided in four quadrants and from each, ten plants were randomly selected, uprooted and check for stem borer's eggs for plant at whorl stage. The number of plants with egg batches and the number of eggs per batch were recorded. Egg batches' counting was done by direct observation of oviposition site of each stemborer's species. For plant at tasseling and soft dough stages the number of plants showing borer damage was recorded, and each maize plant was dissected and the larvae and pupae of the same borer species per plant were counted and placed together in wide-mouthed jars. Larvae were maintained on a diet of young succulent stem of maize, and reared until borer pupation or parasitoid emergence. The egg batches were kept individually in plastic vial in the laboratory at room temperature until borer's larval or parasitoid emergence. Parasitoids were counted per egg mass. Borer pupae and parasitoid cocoons or pupae were kept individually in small round plastic containers for parasitoid or adult moth emergence. Parasitoid specimens were preserved in $70 \%$ alcohol for identification. For egg parasitoid, three kinds of parasitization were calculated by: (a) Mean egg parasitism per field calculated as percentage of eggs parasitized within an individual egg batch, averaged over all egg batches found in the field; (b) the percentage of egg batches with parasitoids per field referred to as "discovery" efficiency by Bin and Vinson (1991) which provides information about the searching ability of a parasitoid; and (c) the percentage of eggs parasitized within discovered egg batches, averaged over all egg batches per field termed "parasitism efficiency" by Bin and Vinson (1991). Dead larvae were placed individually 
in small round plastic containers $\left(150 \times 20 \mathrm{~mm}^{2}\right)$ and kept in the laboratory for parasitoid emergence. In the case fungal infection was suspected, mycosis tests were performed. Dead insects were therefore surface sterilized in $70 \%$ ethanol, dried and incubated on moist filter paper inside sterile Petri dishes $\left(150 \times 20 \mathrm{~mm}^{2}\right)$ for 5 days to confirm fungal infection. The mycosis tests were conducted at the Ecole Supérieure d'Agronomie, Universite de Lomé, Togo. Adult moths were sent to both Institut de Recherche pour le Développement (IRD) and International Centre of Insect Physiology and Ecology (ICIPE) Kenya for species identification. Parasitoids emerging from borer larvae and pupae were counted according to species and preserved as indicated above for later identification by the taxonomists at the Insect Museum of the International Institute of Tropical Agriculture (IITA) in Cotonou, Benin.

On-station field experiment: Two field trials were installed in farmer's field in Yoto district in AEZ V during LR and SR seasons of 2012 to assess the population dynamics of maize stem and cob borers in relation to rainfall pattern. Yoto district was chosen because during previous observations, the presence of many species of stemborer was noticed. For borer species counts, destructive samplings were done biweekly throughout the year, depending on the availability of the maize plants. Samplings of maize began from the whorl stage and covered the entire crop cycle. At harvest, cob borers and stem borers found in the ear were collected. For computing these borers, 10 ears were sampled. On each ear, 100 damaged grains were removed, counted and weighed after removing borer pupae and grain dust by using fine brush. On the same ear, same numbers of

\section{RESULTS}

Species richness, relative abundance and distribution across agroecological zones: Of 76 fields sampled, $42 \%$ were found infested with stem borers. Field infestation varied with the seasons, $34.4 \%$ in long cropping season and $88.3 \%$ in the short cropping season. Three lepidopteran stem borer species (Sesamia calamistis, Busseola fusca, and Eldana. saccharina) belonging to the families Noctuidae and Pyralidae were recorded. Sesamia calamistis was the most abundant borer with $76.02 \%$ of all species while B. fusca represented $21.71 \%$ and $E$. saccharina counting for $2.27 \%$. Eldana saccharina and $B$. fusca were occasionally healthy grains were selected closely to the damaged grains and weighed. The following formula was used to calculate grain loss:

$P_{g}(\%)=\left(P_{h}-P_{d}\right) \times 100 / P_{s}$ where $P_{g}=$ percentage grain loss

$P_{h}=$ mean weight of healthy grains and $P_{d}=$ mean weight of damaged grains.

Survey questionnaire: In each village surveyed for stem borers' infestation, ten farmers were randomly selected and primary data were collected through individual interview method using pre-tested and well structured designed questionnaire. Data include the importance of maize in the farmer's agricultural income, farmer's knowledge on maize stem and ear borers, on their damage and farmer's perception of climate change and mitigation strategies.

Statistical analysis: Differences in plant infestation and pest abundance by season across AEZs were analyzed by analysis of variance (ANOVA) using STATISTICA software. Counts of borer variables were $\log (x+1)$ and percentage data were arcsine square root transformed before analysis. Means were separated with StudentNewman-Keuls (SNK) at $p=0.05$. Coordinates recorded using GPS were used in a Geographic Information System (GIS) for mapping the survey sites and distribution of stemborers' species in the different AEZs. Using species diversity, borer infestation rates and borer density per plant, two plant health maps were established with DIVA 7.5.0 software. Descriptive statistics were used to analyze farmers' perception on climate change and maize insects.

encountered only in AEZ $V$ counting respectively for $15.30 \%$ and $13.00 \%$. Sesamia calamistis was found in all agroecological zones surveyed representing $100 \%$ in AEZ III and AEZ IV and $71.70 \%$ in AEZ V (Figure 2). In $A E Z V$ where the three species were represented, they were found in Yoto and Zio districts (Table 1). According to seasonal abundance $S$. calamistis was the only species found in AEZ III and AEZ IV during the two cropping seasons. In AEZ V, S. calamistis represents $64.62 \%$, E. saccharina $19.12 \%$ and B. fusca $16,25 \%$ during the LR whereas in SR, S. calamistis represent $100 \%$.

Table 1: Mean number of borers per plant ( \pm SE) according to species, relative abundance (\%) and percentage of infested plants at tasseling of maize in three agroecological zones (AEZ) in southern Togo during different seasons of 2012 
Tounou et al..... J. Appl. Biosci. 2013. Farmers perception on effects of climate change on maize stem borers distribution and their natural enemies.

\begin{tabular}{|l|l|c|c|c|c|c|}
\hline AEZ & Districts & \% infested plants & Borer density & \multicolumn{3}{|c|}{ Relative abundance (\%) } \\
\cline { 5 - 7 } & & & \multicolumn{7}{|c|}{ S. calamistis } & E. saccharina & B. fusca \\
\hline \multicolumn{7}{|c|}{ Long cropping season } \\
\hline III & Agou & $44.91 \pm 5.34 \mathrm{~b}$ & $1.83 \pm 0.69 \mathrm{~b}$ & $100.00 \pm 0.00 \mathrm{a}$ & 0 & 0 \\
\hline IV & Kloto & $33.65 \pm 7.58 \mathrm{c}$ & $1.26 \pm 0.67 \mathrm{c}$ & $100.00 \pm 0.00 \mathrm{a}$ & 0 & 0 \\
\hline & Ave & $72.03 \pm 12.58 \mathrm{a}$ & $3.64 \pm 0.89 \mathrm{a}$ & $100.00 \pm 0.00 \mathrm{a}$ & 0 & 0 \\
\hline & Lacs/Bas- & $0.41 \pm 0.36 \mathrm{~g}$ & $0.04 \pm 0.01 \mathrm{e}$ & $100.00 \pm 0.00 \mathrm{a}$ & 0 & 0 \\
& Mono & & & & 0 \\
\hline V & Golfe & $2.97 \pm 2.52 \mathrm{f}$ & $0.12 \pm 0.11 \mathrm{~d}$ & $100.00 \pm 0.00 \mathrm{a}$ & 0 & 0 \\
\hline & Vo & $25.00 \pm 11.90 \mathrm{~d}$ & $1.10 \pm 0.39 \mathrm{c}$ & $100.00 \pm 0.00 \mathrm{a}$ & 0 & 0 \\
\hline & Yoto & $53.34 \pm 12.42 \mathrm{~b}$ & $1.93 \pm 0.60 \mathrm{~b}$ & $17.86 \pm 9.64 \mathrm{c}$ & $30.19 \pm 6.83 \mathrm{~b}$ & $51.95 \pm$ \\
& & & & & $17.87 \mathrm{a}$ \\
\hline & Zio & $18.64 \pm 11.25 \mathrm{e}$ & $0.59 \pm 0.35 \mathrm{~d}$ & $40.64 \pm 4.17 \mathrm{~b}$ & $46.30 \pm 5.07 \mathrm{a}$ & $13.06 \pm 2.54 \mathrm{~b}$ \\
\hline & \multicolumn{7}{|c|}{ Short cropping season } \\
\hline I II & Agou & $72.67 \pm 6.37 \mathrm{a}$ & $5.60 \pm 0.56 \mathrm{a}$ & $100.00 \pm 0.00 \mathrm{a}$ & 0 & 0 \\
\hline IV & Kloto & $64.36 \pm 2.79 \mathrm{~b}$ & $4.96 \pm 0.33 \mathrm{a}$ & $100.00 \pm 0.00 \mathrm{a}$ & 0 & 0 \\
\hline V & Ave & $68.43 \pm 2.35 \mathrm{~b}$ & $5.84 \pm 0.44 \mathrm{a}$ & $100.00 \pm 0.00 \mathrm{a}$ & 0 & 0 \\
\hline
\end{tabular}

\section{Legend}

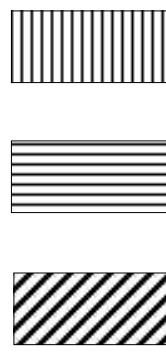

Sesamia calamistis

Eldana saccharina

Sesamia calamistis +

Busseola fusca +

Eldana saccharina

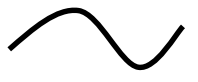

Agro- ecological zone

limit

Ghana

Figure 2: Map showing the distribution of different species among districts

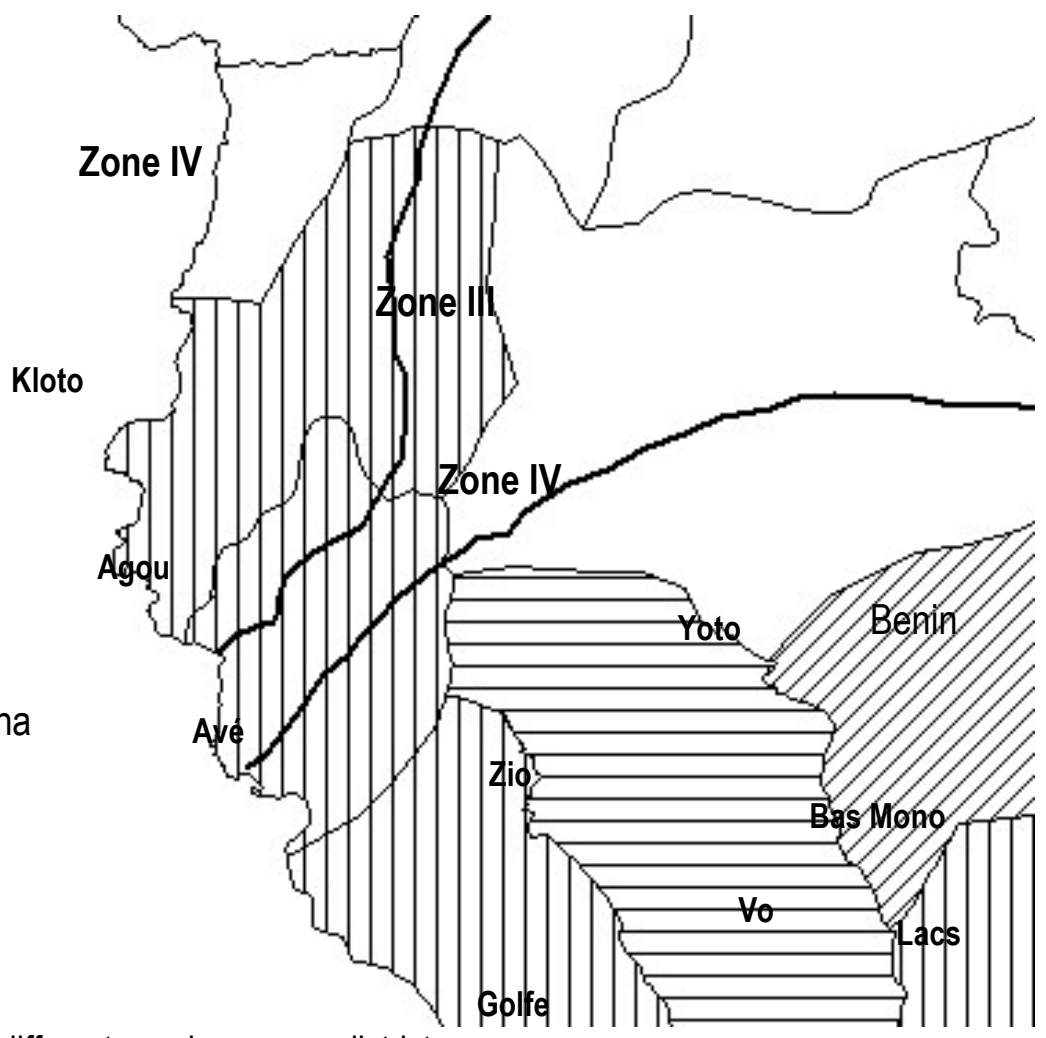

Atlantic Ocean
Season variability of stem borer incidence: Borer densities varied between $0.04 \pm 0.01$ and $3.64 \pm 0.89$ larvae per plant in all AEZ during the long cropping season and between $4.96 \pm 0.33$ and $5.84 \pm 0.44$ larvae per plant during the short cropping season (Table 1). Stem borer incidence expressed as percentage of infested plants varies significantly between the AEZ ( $F=$ $6.49 ; P=0.013 ;$ d.f. $=2$ ). It was more prevalent in the southwestern of the Plateau region (zone IV) than in the other zones (Figure 3). At district level, borer incidence varied significantly from one district to another $(F=6.545$; $\mathrm{P}<0.0001$; d.f. $=7$ ) with the highest incidence in Avé, 
Agou, Yoto and Kloto districts. The Ave district recorded 3.6 larvae per plants (Table 1). Across AEZs, $S$. calamistis plant/field infestation and density varied with the season and were significantly higher in SR cropping (83.82\% and 8.50 larvae/plant) than in the LR cropping (53.18\% and 2.42 larvae/plant) seasons ( $F=39.78 ; P<$ 0.0001 ; d.f. $=1$ for incidence and $F=55.636 P<0.0001$; d.f. $=1$ for borer density). Eggs were rare during the LR cropping season and the majority of the eggs were collected during the SR cropping season. In locations where eggs were collected, mean numbers of egg batch were between $1.0 \pm 0.0$ and $1.27 \pm 0.46$ batch/plant and the number of eggs per batch varied between $16.14 \pm$ 3.63 and $22.20 \pm 7.05$ (Table 2).

Table 2: Mean number of Sesamia calamistis egg batches per plant, eggs per batch, discovery efficiency and percentage egg parasitism due to Telenomus busseolae at the whorl stage of maize in three localities in southern Togo during the short cropping season of 2012

\begin{tabular}{lllll}
\hline Localities & Egg batches/plant & Egg/batch & Parasitism/field (\%) & Discovery efficiency
\end{tabular}

$(\%)$

\begin{tabular}{lllll}
\hline Gadjagan & $1.00 \pm 0.00 \mathrm{~b}$ & $17.20 \pm 3.44 \mathrm{~b}$ & $60.00 \pm 0.44 \mathrm{~b}$ & $80.03 \pm 1.69 \mathrm{a}$ \\
Kévé & $1.27 \pm 0.46 \mathrm{a}$ & $22.20 \pm 7.05 \mathrm{a}$ & $66.67 \pm 0.44 \mathrm{a}$ & $79.02 \pm 1.46 \mathrm{a}$ \\
Tovégan & $1.00 \pm 0.00 \mathrm{~b}$ & $16.14 \pm 3.63 \mathrm{~b}$ & $57.14 \pm 0.46 \mathrm{c}$ & $82.03 \pm 1.29 \mathrm{a}$ \\
\hline
\end{tabular}

\section{Legend}

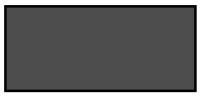

$>50 \%$ Very

high incidence

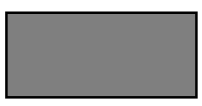

26-50\% High incidence
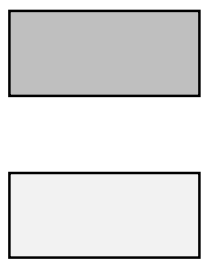

1-12\% Low incidence

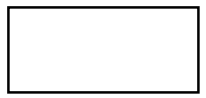

$0 \%$ No

infestation

Agro- ecological zone

limit
1.26

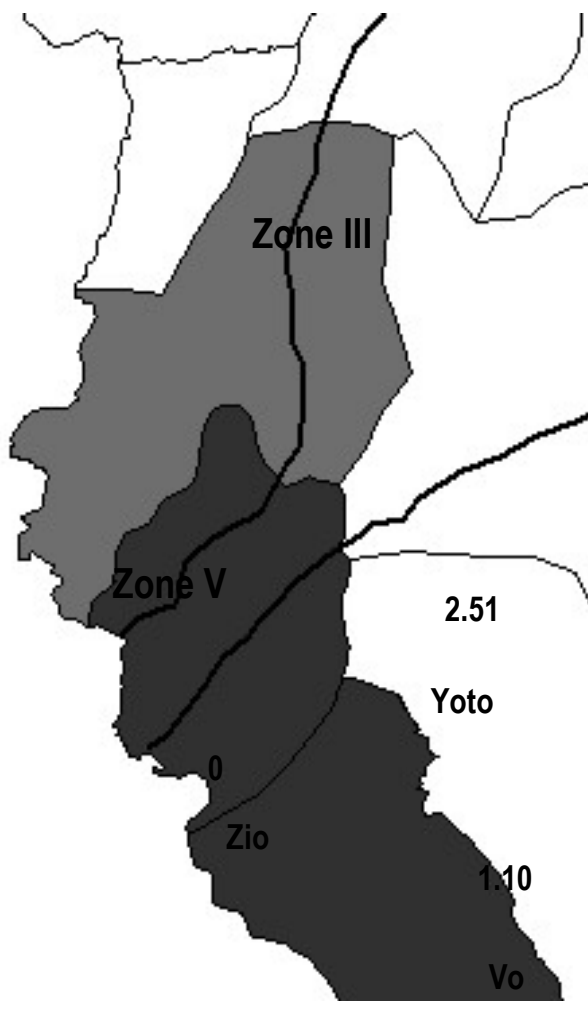

0.11

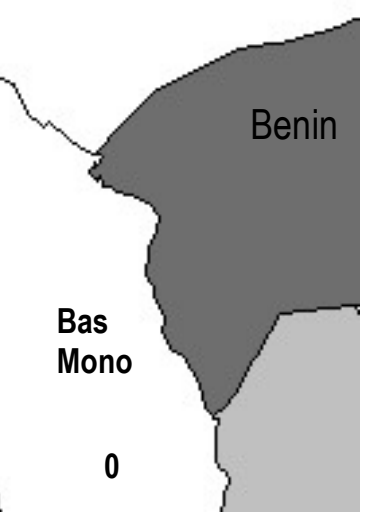

Lacs

Atlantic Ocean

Figure 3: Map showing the incidence of Sesamia calamistis coupled with severity indices during the long cropping season of 2012

On-station field experiment: stem and ear borers' population dynamics: The population dynamics of various stemborers' species in on-station experiment is presented in Figure 4. Peaks in B. fusca larval density occurred around July-September, coinciding with maize growing periods while peaks of $S$. calamistis and $E$. 
saccharina were observed in August and September. With onset of the dry season, larval densities decreased to very low levels. Busseola fusca was the dominant species followed by S. calamistis. From soft dough stage to harvest, ear borers Mussidia nigrivenella and Thaumatotibia leucotreta Meyrick (Lepidoptera: Tortricidae) were found in the ear with $M$. nigrivenella the dominant species representing $83.3 \%$ of all ear borers. Other species commonly stem borers such $S$. calamistis and $E$. saccharina both account for $11.1 \%$. The percent grain loss in the field planted maize due to feeding damage of ear borers was estimated to $31.3 \%$.

Stem borer parasitism and infection: Parasitized eggs were found during the short cropping season in all the infested fields and belonging to the zones or districts where only S. calamistis occurred; the parasitoid species that emerged from those eggs was Telenomus busseolae Gahan (Hymenoptera: Scelionidae). The parasitism rates of $T$. busseolae recorded in field as well as mean discovery efficiencies are presented in Table 2. Sturmiopsis parasitica Curan (Diptera: Tachinidae) was the common larval parasitoid recovered with a parasitism rate ranging from 3 to $8 \%$ during the first cropping season according to districts (Figure 4). In the short cropping season, S. parasitica parasitism rates were 4.78\%, 5.17\% and $5.18 \%$ in Avé, Agou and Kloto districts, respectively. Cotesia spp. was only found in Golf district parasitizing three larvae. No pupal parasitism was observed. During the first cropping season, $B$. bassiana was isolated from up to $5 \%$ of the $S$. calamistis larvae. Similarly percents larval infection by $B$. bassiana were $4.71 \%, 0.43 \%$ and $2.86 \%$, in Avé, Agou and Kloto districts, respectively. The two control agents (S. parasitica and B. bassiana) occurred more significantly in Avé, Agou, Kloto and Yoto districts than in coastal zones (Golfe, Lacs/Bas-Mono districts) (Figure 4).

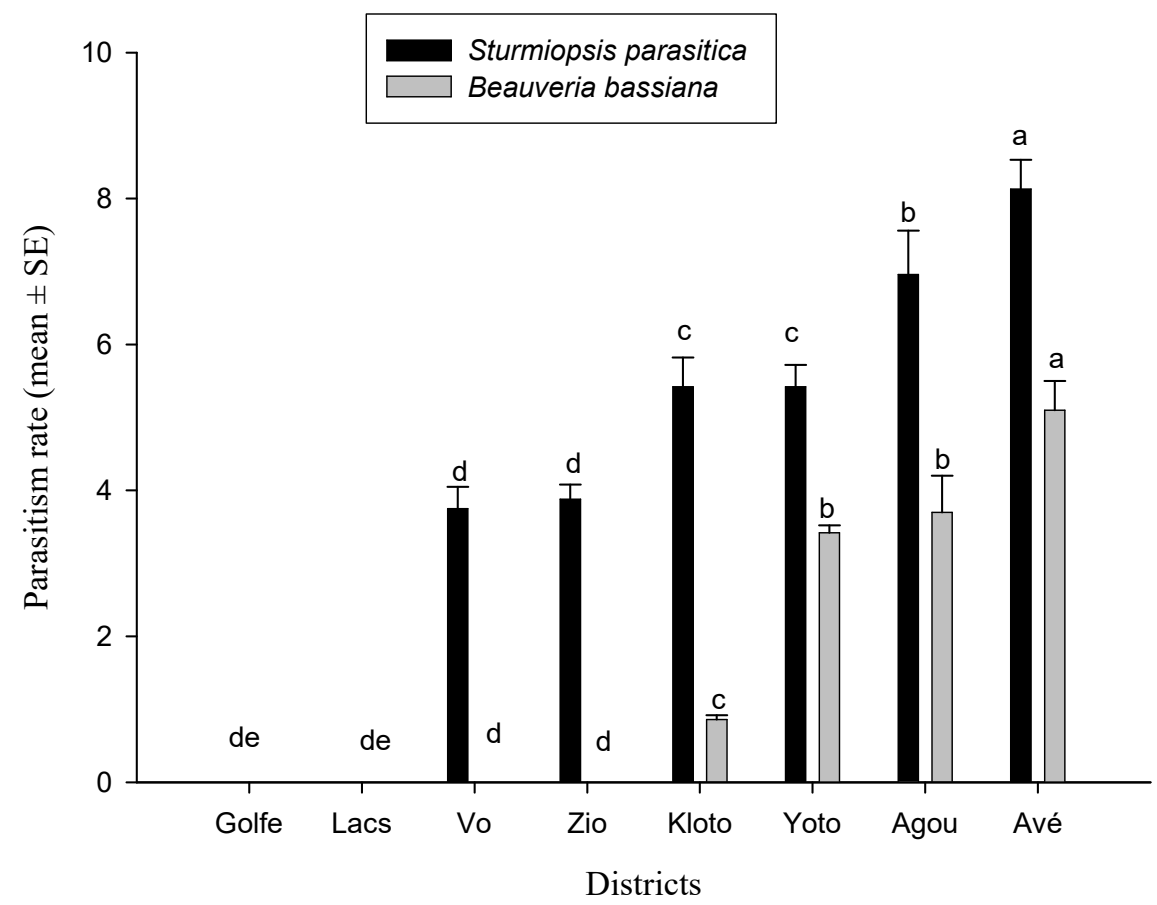

Figure 4: Parasitism and infection rate of Sturmiopsis parasitica and Beauveria bassiana according to the districts during the long cropping season of 2012 

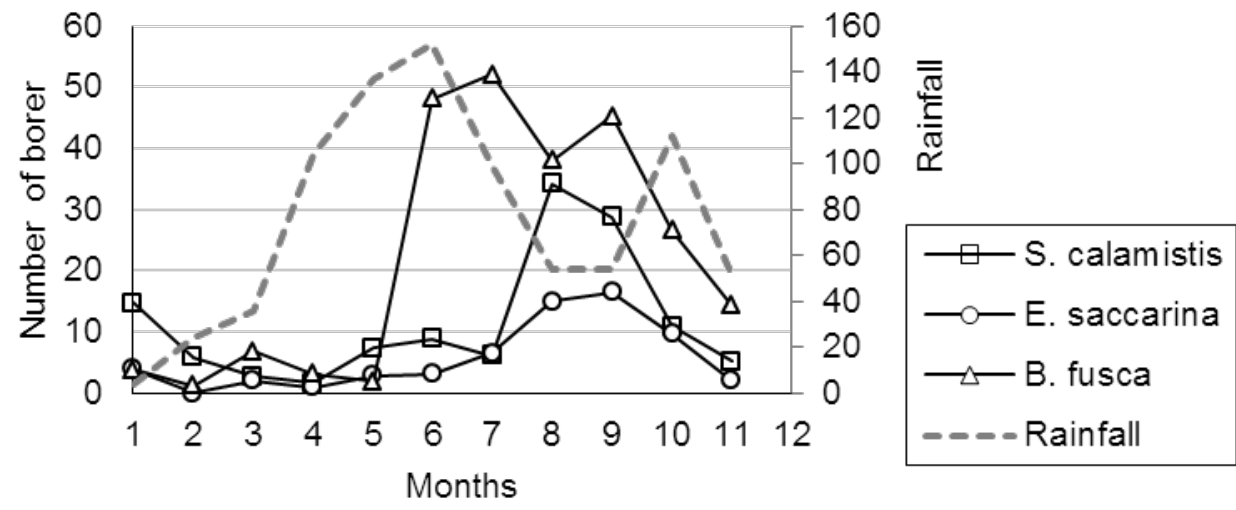

Figure 5: Stem borers dynamics on maize in Yoto district during different seasons of 2012

Farmers' perception on climate change and maize insects: Farmers' perception on climate changes and maize stem and ear bores are presented in Figures $6 \mathrm{~A}$. Farmers indicated that maize represented a mean of $34 \%$ of the total agricultural income. Eighty five percent of the framers could identify stem borer $S$. calamistis and the ear borer M. nigrivenella whereas $15 \%$ could additionally recognize $T$. leucotreta on ear (Figure 6 A). Eighty percent of the farmers perceived that maize damage by borers (dead hearts and bored stems) is negligible in long cropping season but important in the short cropping season (Figure 6 B). Sixty percent of the farmers were capable of estimating plant infestation (damage) that averaged between 5 and 30\% (Figure $6 \mathrm{C}$ ). As for control measures, $90 \%$ of the farmers did not have any measure of managing the stemborers while only $10 \%$ indicated that they use early harvesting to control ear borers (Figure 6 D).Sixty percent of the interviewed farmers perceived climate change as rainfall irregularity and excessive heats. In addition, $30 \%$ and $10 \%$ of the farmers mentioned repeated floods and violent winds, respectively (Figure $6 \mathrm{E}$ ). All of the interviewed farmers indicated that the main cause was deforestation. Farmers enumerated that new insect pests such as Zonocerus variegatus $L$. (Orthoptera: Pyrgomorphidae), termites (Isoptera) and Cicadulina spp. (Hemiptera: Cicadellidae) that have recently become important maize pests in western zone of Plateau region (AEZ IV). Climate change mitigating strategies included among others, the use of early maturity maize varieties and continuous sowing in relation to rainfalls or crop diversification (Figure $6 \mathrm{~F}$ ). 


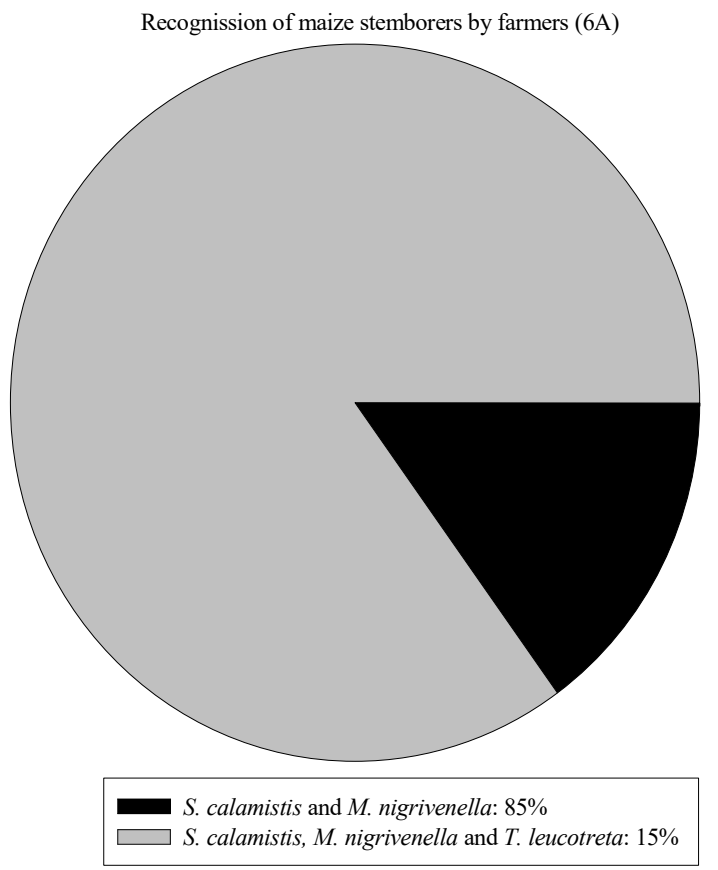

Farmar's hability to estimate yield losses (6C)

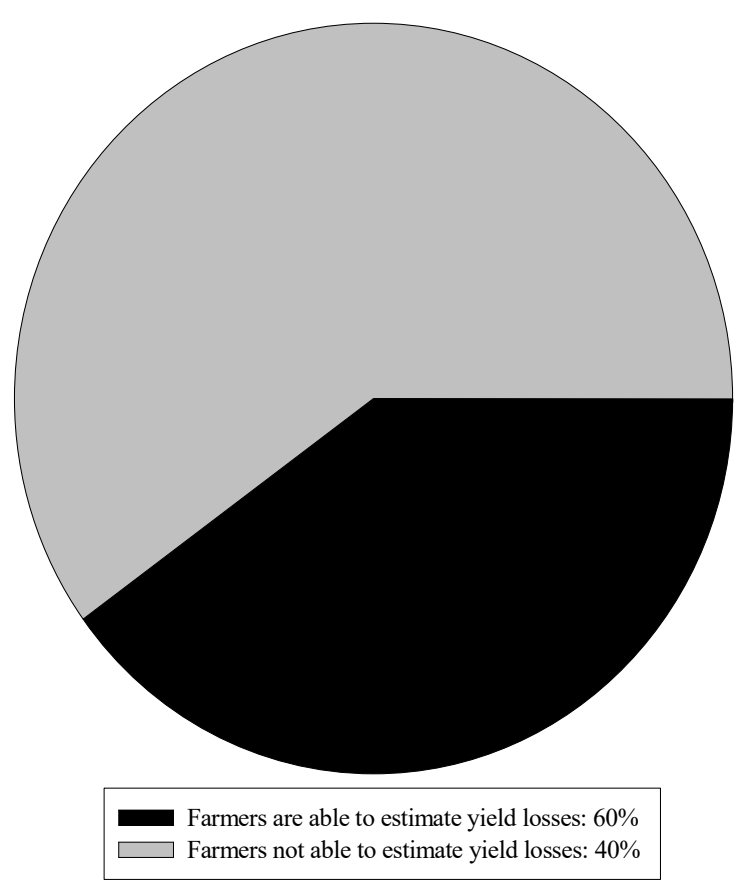

Crop damage perception $(6 \mathrm{~B})$
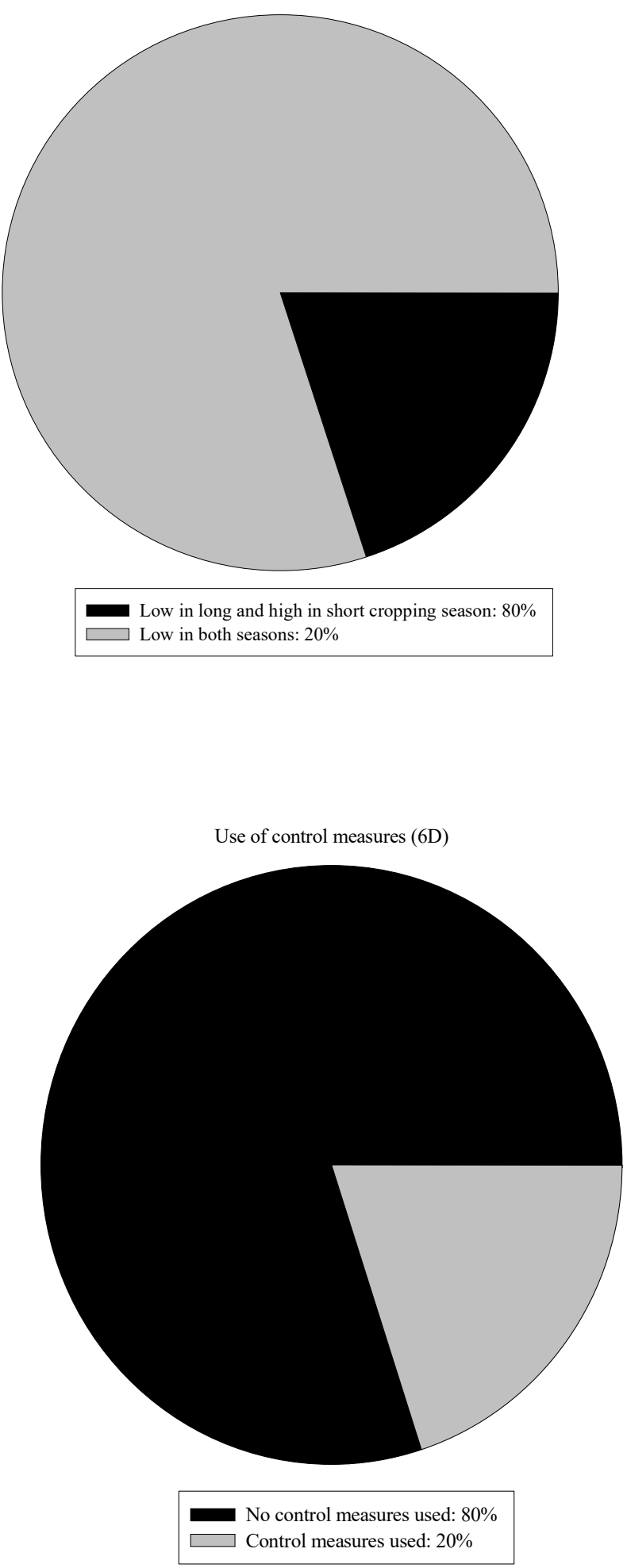
Famer's perception of climate changes (6E)

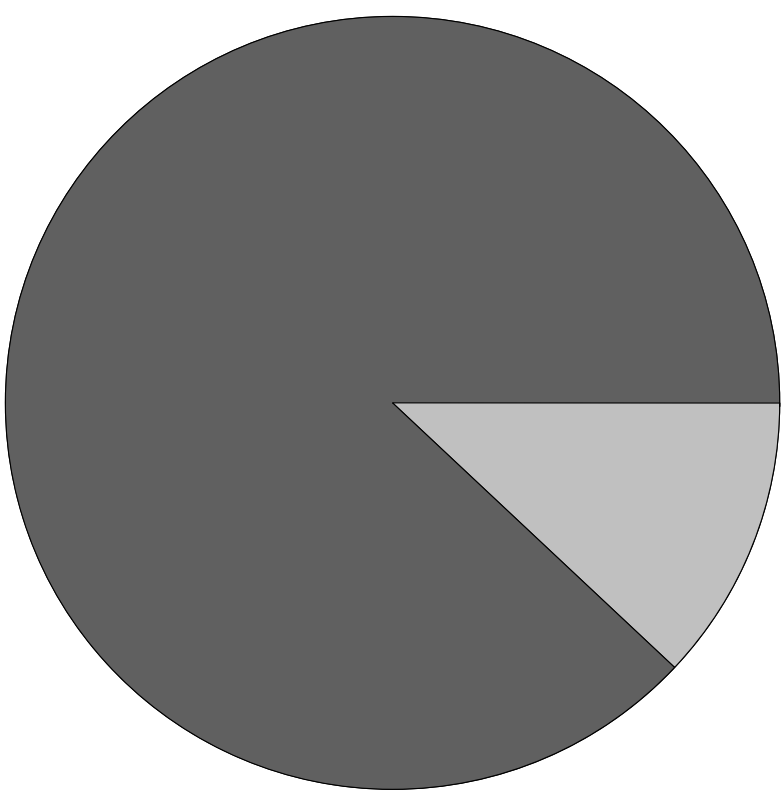

Rainfall irregularity and excessive heat: $80 \%$

Rainfall irregularity, excessive heat and repeated floods: $30 \%$ Rainfall irregularity, excessive heat and violent winds: $15 \%$
Mitigating strategies used to face climate changes $(6 \mathrm{~F})$

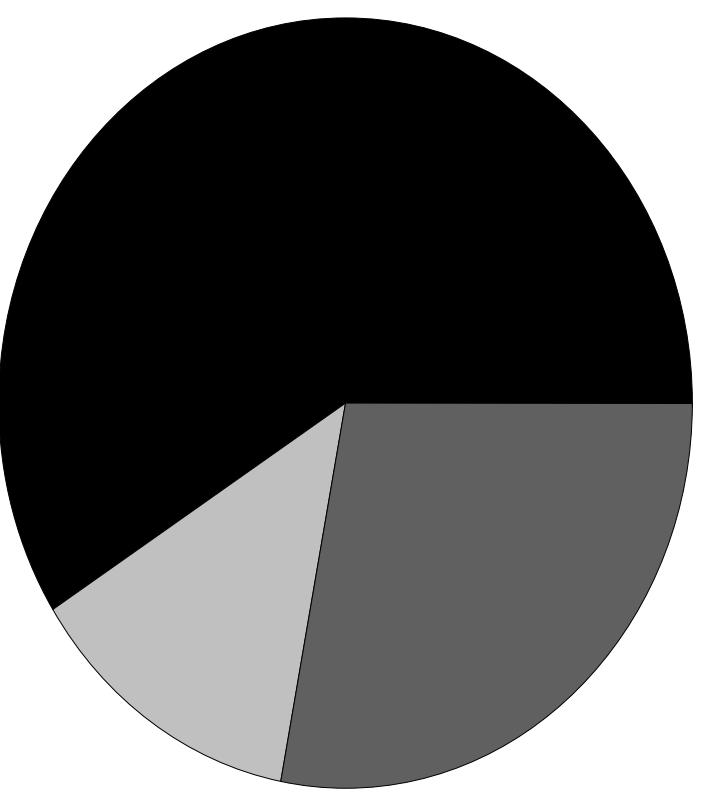

Early maturity maize varieties and spacing out sowing: $59 \%$

Early maturity maize varieties, spacing out sowing and crop diversification: $13 \%$ No measures used: $28 \%$

Figure 6: Climate change and maize stem borers: Farmers' perception on climate change (A), maize stem borers identification by farmers $(B)$, farmers knowledge on control measure against maize cob borers $(C)$, farmers knowledge on crop damage estimation (D) and mitigation measures adopted by farmers (E)

\section{DISCUSSION}

The present study is the first detailed research conducted on maize stem and ear borers in Togo since the surveys conducted by Silvie (1993) in restricted cereal and cottoncropping areas. The results showed that stemborer $S$. calamistis, E. saccharina and B. fusca and the ear borer $M$. nigrivenella cause significant damage and reduce maize yield. Similar results were reported in Benin (Gounou et al., 1994; Schulthess et al., 1997), Ghana (Buadu et al., 2002). This is probably because these countries including Togo share similar agroecological conditions and situated in Dahomey Gap. Moreover results of the countrywide surveys on stem and ear borers in West Africa so far showed that borers oviposited heavily on wild host plants but their relative importance, both on maize and wild grasses varied between regions, eco-zones and within the same eco-zone (Schulthess et al., 1997). Although wild host of stem and ear borers were not included in this study, $S$. calamistis the most frequently reported maize borers in West Africa (BosquePérez and Mareck 1990; Gounou et al., 1994; Schulthess et al., 1997), were found in the three agroecological zones surveyed in Togo. Similarly, Gounou et al. (2009) showed that the predominant species in southern Benin were $S$. calamistis and $E$. saccharina. As for $B$. fusca it was found only in Yoto district causing serious damages on maize. In contrast to this, Harris (1962) described $B$. fusca as the most abundant species and major pest of sorghum in the drier parts of the Guinea and Sudan savannah, while Tams and Bowden (1953) stated that in west Africa, $B$. fusca was the most serious in the wetter parts of the Guinea savannas. In Cameroon, $B$. fusca is the most abundant species on maize across all ecological zones (Cardwell et al., 1997; Ndemah et al., 2001a). Matama-Kauma et al. (2007) reported that variations in dominance among these species could be a result of specific adaptations in their ecological requirements. Furthermore, given the geographic distribution of stem borers and the role of wild host plants, Schulthess et al. (1997) proved that the differences in relative importance of species may be due to differences in human population densities including intensity of cereal cultivation (Harris, 1962). Increasing population pressure and the 
concomitant expansion of agricultural areas often result in deforestation and displacement of wild habitats of borers, which probably affect the population dynamics of both borers and their natural enemies. Kloto district, which was a very dense forest zone where coffee and cocoa are usually produced is currently subjected to serious deforestation for cereals and yam production. Moreover, in most locations, it is observed that borer's larvae particularly third instars tended to be aggregate in unopened maize inflorescences instead of stem or ear. This could indicate that female moths lay their eggs on all phenological stages of the plant not only on the leaf whorl but also on tassels and on ears. Is this change in oviposition behaviour of maize stem borers related to adaptation to changing of climatic conditions? This should be elucidated in future studies in all agroecological zones in Togo.

In most locations surveyed, the egg parasitoid $T$. busseolae, the larval parasitoids $S$. parasitica and Cotesia spp., and entomopathogenic fungus $B$. bassiana are the main biotic mortality factors of the stem borers in Togo. The latter was recorded and tested successfully on S. calamistis in Benin (Cherry et al., 1999). Telenomus busseolae is an important natural biocontrol agent against $S$. calamistis on maize with mean parasitism more than $80 \%$. This corroborates with findings of studies conducted in Benin where mean parasitism was more than $80 \%$ (Sétamou and Schulthess, 1995; Schulthess et al., 1997). With these relatively high egg parasitism rates on maize, the parasitoid could maintain the noctuid stem borers at low level and as concluded by Schulthess et al. (2001), S. calamistis is usually not of economic importance in the Dahomey Gap, which includes parts of Benin, Togo and Ghana. According to Ndemah (1999), egg parasitism was the main reason for the relatively low $B$. fusca densities found during the second season in the forest zone. Parasitism of the tachnid S. parasitica, although not as high as compared to that by $T$. busseolae, suppresses less than $10 \%$ of the larvae. This low parasitism recorded can be explained by the functional response of the parasitoid and its guild. According to Smith et al. (1993) and Gounou et al. (2009) S. parasitica utilizes a planidialingress host attack strategy whereby mobile first instar maggots (planidia) are deposited on moist frass at stem borer tunnel entrances. The planidia then have to move through the frass to attack and penetrate the host larva inside the tunnel. Ndemah et al. (2002) found that parasitism of $S$. calamistis by the larval parasitoid $S$. parasitica was higher on the thin-stemmed grasses than on the large-stemmed maize. It was concluded that part of the reason for the differences in parasitism rates was due to differences in accessibility of the host inside the stem. Sturmiopsis parasitica appeared to be common on $S$. calamistis and E. saccharina in West Africa (Gounou et al., 2009) as observed in the present study, while in Cameroon it was recovered only once, and from $B$. fusca (Ndemah et al., 2001b, 2007). The third parasitoid Cotesia spp. recorded sporadically in southern Togo could result from the establishment of $C$. sesamiae in southern Benin (Hailemichael et al., 2008). However, further morphological and molecular analysis of the Cotesia species recorded in southern Togo is needed to confirm this hypothesis.

The present study indicated that farmers are aware of the changes in climate. Farmers perceived climatic variations through excessive heat, rainfall irregularities, regular floods and violent winds. Similar perceptions were shown in studies conducted by Mertz et al. (2009) in the Sahel, Apata et al. (2009) in southwestern in Nigeria and Nyanga et al. (2011) in Zambia. The variability of rainfall leads to variability in sowing dates and as a consequence, varying phonological stages of maize plant were observed in all agroecological zones resulting in continuous stem and ear borers' infestation. Based on the estimation given by farmers, potential losses were relatively high in low potential areas (Hassan et al., 1998; De Groote 2002). 


\section{ACKNOWLEDGMENTS}

The present study at Ecole Supérieure d'Agronomie (ESA), Université de Lomé (UL) was supported by the grant of International Foundation of Science (IFS) to Agbéko Kodjo Tounou

\section{REFERENCES}

Afidégnon D, 1999. Les mangroves et les formations associées du Sud-Est du Togo : Analyse écofloristique et cartographie par télédétection spatiale. Th. doct., Univ. Bénin (Togo), $237 \mathrm{p}$.

Akpagana K, 1992. Espèces nouvelles pour la flore du Togo. Ann. Univ. Bénin, sect. sci., 10: pp. 2532.

Apata TG, Samuel KD, Adeola AO, 2009. Analysis of Climate Change Perception and Adaptation among Arable Food Crop Farmers in South Western Nigeria. International Association of Agricultural conomists' 2009 Conference, Beijing, China.

Batalden RV, Oberhauser K, Peterson AA, 2007. Ecological niches in sequential generations of eastern North American Monarch butterflies (Lepidoptera: Danaidae): the ecology of migration and likely climate change implications. Environmental Entomology, 36: 1365-1373.

Bin $F$ and Vinson SB, 1991. Efficacy assessment in egg parasitoids (Hymenoptera): proposal for a unified terminology. Trichogramma and other egg parasitoids San Antonio (TX, USA).23-27 September, Ed. INRA, Paris; (les colloques no. 56).

Bosque-Pérez NA and Mareck JH, 1990. Distribution and species composition of lepidopterous maize borers in southern Nigeria. Bulletin of Entomological Research, 80: 363-368.

Bosque-Pérez NA., and Mareck JH, 1991. Effect of the stem borer Eldana saccharina Walker (Lepidoptera: Pyralidae) on the yield of maize. Bulletin of Entomological Research 81, 243247.

Bosque-Pérez NA and Schulthess F, 1998. Maize: West and Central Africa. pp. 11-24 In: A. Polaszek (ed.). African Cereal Stem Borer: Economic Importance, Taxonomy, Natural Enemies and Control, CAB International, England, 530p

Buadu EJ, Gounou S, Cardwell KF, Mochiah B, Botchey M, Darkwa E, Schulthess F, 2002. Distribution and relative importance of insect pests and diseases in Southern Ghana. African Plant Protection, 8: 3-11.

Cardwell K, Schulthess F, Ndemah R., Ngoko Z, 1997. A systems approach to assess crop health and maize yield losses due to pests and diseases in Cameroon. Agriculture Ecosystème \& Environment, 65: 33-47.

Cherry AJ, Lomer CJ, Djegui D, Schulthess F, 1999. Pathogen incidence and their potential as microbial control agents in IPM of maize stem borers in West Africa. BioControl 44: 301-327.

De Groote H, 2002. Maize Yield Losses From Stemborers in Kenya. Insect Science and its Application, 22: 89-96.

DRP, (1985) : Analyses régionales, Région Maritime Ministère du Plan et de l'Industrie, Lomé

Endrödy-Younga S, 1968. The stem-borer Sesamia botanephaga Tams and Bowden (Lepidoptera: Noctuidae) and the maize crop in Central Ashanti, Ghana. Ghana Journal of Agricultural Sciences, 1:103-131.

Gounou S, Jiang N, Schulthess F, 2009. Long-term seasonal fluctuations of Lepidopteran cereal stemborers and their natural enemies on maize and wild host plants in southern Benin. Insect Science, 16: 329-341.

Gounou S, Schulthess F, Shanower T, Hammond WHO, Braima $\mathrm{H}$, Cudjoe AR, Adklaoe R, Antwi KK, Olaleye I, 1994. Stem and ear borers of maize in Ghana, Plant Health Management Research Monograph 4, International Institute of Tropical Agriculture, Ibadan, Nigeria, 23pp

Hailemichael Y, Schulthess F, Smith JJr, Overholt W, Chabi-Olaye A 2008. Resource allocation and bionomic of indigenous and exotic Cotesia (Hymenoptera: Braconidae) species associated with West African cereal stem borer. Bulletin of Entomological Research, 98: 405-415.

Harris KM, 1962. Lepidopterous stem borers of cereals in Nigeria. Bulletin of Entomological Research, 53: 139-171

Hassan RM, Corbett JD, Njoroge K, 1998. Maize Technology Development and Transfer: A GIS Application for research planning in Kenya, $p$. 43-68. CAB International, Wallington, Oxon, UK.

Kokou K, 1998. Les mosaïques forestières au sud du Togo : biodiversité, dynamique et activités humaines. Th. doct., Univ. Montpellier II, 140 p. 
Matama-Kauma T, Schulthess F, Mueke JM, Omwega CO, Ogwang JA, 2007. Impact of wild grasses planted as border rows on stemborer infestations in maize in Uganda. Annales de la Société Entomologique de France, 42 : 455460.

Mertz O, Mbow C, Reenberg A, Diouf A, 2009. Farmers' Perceptions of Climate Change and Agricultural Adaptation Strategies in Rural Sahel. Environmental Management, 43: 804816.

Moyal P, 1988. Crop losses due to insects in the savanna area of Ivory Coast: A review. Tropical Pest Management, 34: 455-459

Ndemah R, 1999. Towards an integrated crop management strategy for the African stalk borer, Busseola fusca (Fuller) (Lepidoptera: Noctuidae) in maize systems in Cameroon. $\mathrm{PhD}$ thesis. $145 \mathrm{p}$

Ndemah R, Gounou S, Schulthess F, 2002. The role of wild grasses in the management of lepidopterous cereal stemborers on maize in western Africa. Bulletin of Entomological Research, 92: 507-519.

Ndemah, R, Schulthess F, Korie S, Borgemeister C, Cardwell KF, 2001a. Distribution, relative importance and effect of lepidopterous borers on maize yields in the forest zone and midaltitude of Cameroon. Journal of Economic Entomology, 94: 1434-1444

Ndemah R, Schulthess F, Korie S, Borgemeister C, Cardwell KF, 2001b. Distribution, relative importance and effect of lepidopterous borers on maize yields in the forest zone and midaltitude of Cameroon. Journal of Economic Entomology, 94: 1434-1444.

Ndemah R, Schulthess F, Leru B, Bame I 2007. Lepidopteran cereal stemborers and associated natural enemies on maize and wild grass hosts in Cameroon. Journal of Applied Entomology, 131: 658-668.

Ndemah R, Schulthess F, Poehling H-M, Borgemeister $C, 2001$. Natural enemies of lepidopterous borers on maize and elephant grass in the forest zone of Cameroon with special reference to Busseola fusca (Fuller) (Lepidoptera: Noctuidae). Bulletin of Entomological Research, 91: 205-212.

Nyanga HP, Johnsen HF, Aune JB, 2011. Smallholder Farmers' Perceptions of Climate Change and Conservation Agriculture: Evidence from Zambia. Journal of Sustainable Development, 4: 73-85

Parmesan C, Ryrholm N, Stefanescu C, Hill JK, Thomas CD, Decimon H, Huntley B, Kaila L,
Kullberg J, Tammaru T, Tennent WJ, Thomas JA, . Warren M, 1999. Poleward shifts in geographical ranges of butterfly species associated with regional warming. Nature, 399: $579-583$

Polaszek A, 1998. African Cereal Stem Borers: Economic Importance, Taxonomy, Natural Enemies and Control. CAB International in association with the ACP-EU Technical Centre for Agricultural and Rural Co-operation CTA, pp. 530.

Schulthess F, Chabi-Olaye A, Goergen G, 2001 Seasonal fluctuation of Sesamia calamistis (Lepidoptera: Noctiudae) populations in maize fields in southem Benin. Biocontrol Science and Technology, 11: 756- 777 .

Schulthess F, Bosque-Pérez NA, Chabi-Olaye A, Gounou S, Ndemah R, Goergen G, 1997. Exchanging natural enemies species of lepidopterous cereal stemborers between African regions. Insect Science and its Application, 17: 97-108.

Sétamou M and Schulthess F, 1995. The influence of egg parasitoids belonging to the Telenomus busseolae (Hymenoptera: Scelionidae) species complex on Sesamia calamistis (Lepidoptera: Noctuidae) populations in maize fields in Southern Benin. Biocontrol Science and Technology, 5: 69-81.

Sétamou M, Schulthess F, Poehling H-M, Borgemeister C, 2000. Monitoring and modeling of field infestation and damage by the maize ear borer Mussidia nigrivenella Ragonot (Lepidoptera: Pyralidae) In Benin, West Africa. West Africa. Journal of Economic Entomology, 93: 650-657.

Shanower T, Schulthess F, Gounou S, 1991. Distribution and abundance of some stem and cob borers in Benin. Plant Health Management Research Monograph N01, International Institute of Tropical Agriculture, Ibadan, Nigeria, 18pp.

Silvie P, 1993. Nouvelles données sur Mussidia nigrivenella Ragonot (Lepidoptera: Pyralidae) au Togo. Insect Science and its Application, 14: 643-649.

Smith JWJr, Wiedenmann RN, Overholt WA, 1993. Parasites of Lepidopteran Stemborers of Tropical Graminaceous Crops. ICIPE Science Press, Nairobi. 81p.

Tams WHT and Bowden J, 1953. A revision of the African species of Sesamia Guenee and related genera (Agrotidae: Lepidoptera). Bulletin of Entomological Research, 43: 645678. 
Tounou et al..... J. Appl. Biosci. 2013. Farmers perception on effects of climate change on maize stem borers distribution and their natural enemies.

Trnka M, Muškab F, Semerádováa D, Dubrovsky' c M, Kocmánkováa E, Žaluda Z, 2007. European corn borer life stage model: regional estimates

of pest development and spatial distribution under present and future climate. Ecological Modelling, $207: 61-84$. 